Науковий вісник Дьвівського національного університету ветеринарної медицини та біотехнологій імені С.3. Гжицького

\author{
Scientific Messenger of Lviv National University \\ of Veterinary Medicine and Biotechnologies
}

UDC 637'8:3384395

\title{
Method of determining the relaxation force of fish
}

\author{
S.L. Shapoval, O.V. Romanenko \\ Kyiv National University of Trade and Economics, Kyiv, Ukraine
}

Article info

Received 29.08.2018

Received in revised form 26.09.2018

Accepted 27.09.2018

Kyiv National University of Trade and Economics, Kyoto Street, 19 , office 119, Kyiv, 02156, Ukraine. Tel: + 38-050-137-27-05 E-mail:Elenrom@ukr.net

Shapoval, S.L., \& Romanenko, O.V. (2018). Method of determining the relaxation force of fish. Scientific Messenger of Lviv National University of Veterinary Medicine and Biotechnologies. 20(90), 7-11. doi: $10.32718 /$ nvlvet9002

There have been repeated cases of fish sales during the spawning period in the Ukrainian market, which consumer value is much lower, and fish re-freezing products. The aforementioned methods of abuse can be identified by commodity experts, while ordinary consumers, unfortunately, often cannot independently determine the quality of the fish. The basis of the vast majority of sensory checks of the elastic properties of fish is the process of compressing the product. The advantage of determining the surface relaxation rate is that it is non-destructive testing and the product appearance of the product after the examination does not change. However, this method requires some practical experience and depends essentially on the qualifications of an expert. The method and equipment for instrumental assessment of relaxation compression deformation force to define structural and mechanical properties of fish is given; it makes possible to minimize the experimenter influence on the results and obtain a quantitative value of relaxation speed at anytime in the experiment. The method of investigation of relaxation force and the rate of fish carcasses relaxation was theoretically grounded. A 3D-diagram of force that act on the indenter while pressing the surface of white cupid carcass is given. The type of dynamometer and measuring device for fixation of relaxation force dynamics is grounded. There was developed the sensor for determining the dynamics of the relaxation force with a constant depth of lowering of the indenter; scheme and photo of it is given. The mathematical models of relaxation velocity at axial deformation of compression and tension were constructed. The proposed method for quantifying the relaxation rate involves the construction of a compression deformation curve in the second of pressing a fish carcass and determining their angle of inclination. Based on the mathematical analysis of the deformation curves, it was found that for chilled meat of white cupid for 8 hours of storage, the relaxation rate at strain by $33 \%$ is greater than for the compression deformation; the primary force upon pressing on the product is $23 \%$ greater than when the specimen is subjected to a similar crosssectional area. The developed methodology and system allows to determine the relaxation force when squeezing a fish sample just like a commodity science expert does and make quantitative assessment of its structural and mechanical properties. idella.

Key words: structural and mechanical properties, relaxation force, speed (rate), ctenopharyngodon

\section{Спосіб визначення релаксаційного зусилля тушок риби}

\author{
С.Л. Шаповал, О.В. Романенко
}

Київський національний торговельно-економічний університет, м. Київ, Украӥна

На ринку Украӥни неодноразово спостерігалися випадки продажів риби нерестового періоду, споживча иінність якої є значно нижчою, та рибних продуктів повторної заморозки. Вищезгадані способи зловживань можуть бути ідентифіковані експертамитоварознавцями, тоді як пересічні споживачі нажаль, частіше не можуть самостійно визначити якість риби. В основу переважної більшості сенсорних перевірок пружних властивостей риби покладено процес стискання продукту. Перевагою визначення швидкості релаксації поверхні є те, щзо це неруйнівний контроль і товарний вигляд продукту після експертизи не змінюється. Проте такий спосіб вимагає певного практичного досвіду та суттєво залежить від кваліфікачії експерта. Запропоновано методику та обладнання для інструментальної оцінки релаксаційного зусилля деформації стиску для визначення структурномеханічних властивостей риби, що дозволяє мінімізувати вплив експериментатора на результати та отримати кількісні значення швидкості релаксації в будь який момент часу експерименту. Теоретично обтрунтовано спосіб дослідження релаксаційного зусилля та швидкості релаксації тушок риби. Наведено тривимірну схему сил, щьо діють на індентор під час натискання на повер- 
хню тушки білого амура, враховуючи зсув шарів м'язів. Обтрунтовано тип динамометра та вимірювального приладу для фіксації динаміки релаксаційного зусилля. Створено датчик для визначення динаміки релаксаційного зусилля із сталою глибиною опускання індентора, наведено його схему та фотографію. Встановлено відмінність між швидкістю релаксації при деформації стиску та розтягу. Побудовано математичні моделі швидкості релаксацї при осьовій деформації стиску та розтягу. Запропонована методика кількісної очінки швидкості релаксачії передбачає побудову дотичних до кривої деформачії стиску на другій секунді натискання на тушку риби. Та визначення їх кута нахилу. На підставі математичного аналізу кривих деформації, встановлено, щзо для охолодженого м'яса білого амура 8 годин зберігання швидкість релаксаиії при деформачї розтягу на $33 \%$ більшою ніж при деформацї стиску, початкове зусилля при надавлюванні на продукт на 23,5\% більше ніж при розтягуванні зразка аналогічної площі поперечного перерізу. Розроблена методика та система дозволяє визначити релаксаційне зусилля при здавлюванні зразка риби подібно до того, як ие робить товарознавець-експерт та кількісно оцінити його структурно-механічні властивості.

Ключові слова: структурно-механічні властивості, релаксаиійне зусилля, швидкість релаксаиії, датчик для визначення релаксаційного зусилля, білий амур.

\section{Вступ}

На сьогоднішній день більшість гідробіонтів добувається за межами України, що, відповідно, визначає їх ціну та створює передумови для зловживань недобросовісними підприємцями.

На ринку України неодноразово спостерігалися випадки продажів лососевих риб нерестового періоду, біологічна цінність яких є значно нижчою. Також було зафіксовано непоодинокі випадки продажу рибних продуктів повторної заморозки (Sydorenko, 2006).

Всі вищезгадані способи фальсифікації рибної продукції можуть 3 легкістю бути визначеними досвідченими експертами (Sahin and Servet, 2006), тоді як пересічні споживачі, нажаль, найчастіше не завжди можуть самостійно визначити якість риби.

В основу переважної більшості сенсорних перевірок структурно-механічних властивостей рибної сировини покладено процес стискання продукту. Тобто на продукт натискають пальцем та, після зняття зусилля, візуально спостерігають за швидкістю вирівнювання його поверхні (Safronova, 1998).

Однією з переваг визначення швидкості релаксації поверхні продукту є той фактор, що це неруйнівний контроль і товарний вигляд продукту після експертизи не змінюється.

Проте такий спосіб оцінки консистенції вимагає певного практичного досвіду, суттєво залежить від самого експериментатора. Також складно кількісно оцінити пружність риби (Guc' et al., 2006).

Метою роботи є удосконалення методу визначення реологічних властивостей тушки риби так, щоб він був максимально наближений до сенсорної оцінки експертом-товарознавцем.

Відповідно до мети були поставлені завдання: встановити різницю між релаксаційними зусиллями при деформації розтягу та стиску, та визначити яка із зазначених характеристик більше відповідає сенсорній експертній оцінці; розробити датчик для фіксування динаміки релаксаційного зусилля при деформації стиску, який може працювати безпосередньо на тушці риби без попередньої підготовки зразка.

Намагання інструментально виміряти релаксацію продуктів тваринного походження неодноразово відбувалися і раніше іншими науковцями.

Зокрема в’язкісно-реологічні властивості колагену 3 коропа визначали на структурометрі, що дозволило визначити динаміку, проте для неруйнівного дослідження структурно-механічних властивостей неодно- рідних структур структурометри не підходять (Safandowska and Pietrucha, 2013).

Науковцями з Національного університету харчових технологій запропоновано визначати консистенцію м'яса риби за допомогою гравітаційного пенетрометра, що дозволяє визначати готовність пресервів, коли органолептична оцінка неможлива (Guc' et al., 2006). Такий спосіб дозволяє визначити міцність філе риби, але не дозволяє визначити ані межу міцності шкіри ні пружні характеристики зразка.

Було визначено релаксаційне зусилля філе індика різного терміну зберігання та наведено математичний спосіб його оцінювання (Shapoval, 2017).

Також запропоновано використовувати такий параметр, як швидкість релаксації для дослідження реологічних властивостей рибних пресервів (Romanenko, 2013).

Проте, в усіх зазначених вище випадках досліджувалося релаксаційне зусилля деформації розтягу, а в рекомендаціях щодо сенсорної оцінки структурномеханічних властивостей тушки риби вказано, що потрібно натиснути на поверхню продукту (Safronova, 1998).

Окрім того, аналіз релаксації розтягу потребує вирізання зразків із чіткими геометричними розмірами, що не завжди зручно у виробничих умовах.

Дослідження впливу хімічних сполук, зокрема гідроколоїдів, на механічні властивості м'яса риби відбувалося через визначення модуля пружності (Ramírez et al., 2011), проте цей метод не дозволяє оцінювати швидкість релаксації, яка $є$ вирішальною для сенсорної оцінки пружних властивостей риби.

Також було визначено температурну залежність межі міцності на розрив та граничної напруги зсуву м'яса палтуса та тунця (Iso et al., 1986). Було застосовано руйнівний метод, який зручно використовувати у лабораторії, проте у виробничих умовах цей метод застосовувати не раціонально, через втрату зразком товарного вигляду.

\section{Матеріал і методи досліджень}

Для реєстрації та фіксування результатів роботи датчиків було обрано вимірювальну систему концепції “все в одному” MIG-1.4 (Shapoval et al., 2017). Головним критерієм вибору вимірювальної системи була зручність проведення експерименту у виробничих умовах. 
Розроблений датчик було відкалібровано відповідно до значень динамометра PD-3N виробництва TOB "ITM".

Апробацію розробленого датчика проводили на охолодженій тушці білого амуру (Ctenopharyngodon idella), яка зберігалася протягом 8 годин.

Сенсорну експертну оцінку пружності тушки білого амуру проводили провідними фахівцями в лабораторіях кафедри товарознавства, управління безпечністю та якістю Київського національного торговельноекономічного університету.

Релаксаційне зусилля риби визначали у трикратному повторюванні, щоразу на новому місці в товщі м'язів близько центру тушки.

\section{Результати та їх обговорення}

В тушці риби шари м'язової тканини розташовано під кутом до повздовжньої осі, тому поверхня під навантаженням прогинається не рівномірно, а дещо зсуваючись у напрямку голови. Протидію шарів продукту деформації при натисканні плоского індентора при умові, що поверхня не зруйнована, зображено на рис. 1.



Рис. 1. Схема сил при натисканні на поверхню продуту індентором із розширеним наконечником.

1 - індентор; 2 - диск; 3 - шкірочка продукту; 4 - шари м'язової тканини риби; 5 - сила бокового зміщення індентора; 6 - сила опору руху індентора (релаксаційне зусилля);

7 - сила натискання на індентор; 8 - сила бокової деформації

Як видно із рис. 1. на індентор (2) діє деформуюча сила, що направлена у той же напрямок (5), в якому i зсуваються шари м'яса риби (8). Тому при визначенні релаксаційного зусилля важливо зафіксувати індентор вертикально, щоб мінімізувати вплив зміщення шарів продукту по горизонталі на значення сили релаксації.

Кут між напрямом руху індентора (6) та вектором бокового зміщення (5) складає від 3 до $9^{\circ}$, що може суттєво вплинути на результати експерименту, тому потрібна додаткова бокова стабілізація та, відповідно, збільшена довжина індентора.

Оскільки на ринку України відсутні датчики для визначення релаксаційного зусилля деформації стиску для харчової сировини, то було розроблено датчик оригінальної конструкції.

Система передачі даних розробленого датчика повністю сумісна 3 цифровими протоколами вимірювальних приладів універсального вимірювального приладу виробництва ТОВ “ІТМ” м. Харків (Elektronnyj vymirjuval'nyj blok) та серії приладів MIG розробки Київського національного торговельно-економічного університету.

Датчик для дослідження релаксаційного зусилля при надавлюванні на продукт виготовлено в корпусі системи моніторингу FreeStyle Libre. У подальшому планується надрукувати корпус датчика за 3D принтері.

Для вимірювання зусилля релаксації використано тензометричний динамометр із межами вимірювання 0...49 Н, та ціною поділки 0,98 мН. Період передачі даних у використаного динамометра більше, ніж у пружинних, і складає 0,1 с, чого цілком достатньо для вимірювання релаксаційного зусилля. Динамометр живиться напругою 3В і струмом 200 мА.

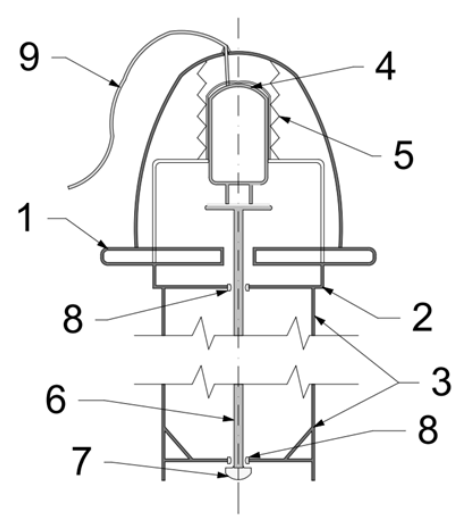

a)

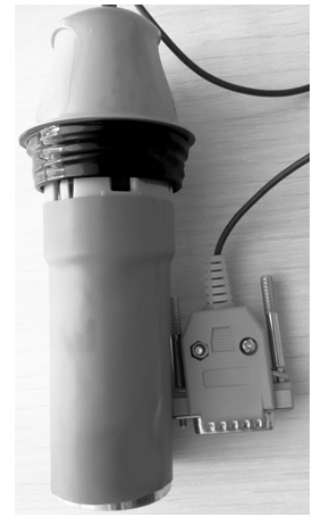

b)
Рис. 2. Схема та фотографія датчика для вимірювання релаксаційного зусилля філе риби.

a) -схема датчика (1 - корпус-ручка; 2 - втулка; 3 - направляюча труба; 4 - динамометр; 5 - пружина; 6 - індентор;

7 - наконечник; 8 - полімерін шайби; 9 - кабель живлення та передачі даних на MIG-1.4); b) - фотографія датчика

Головною перевагою динамометра (4) є мінімальний хід індентора (6), який складає 1,1 мм при повному навантаженні. У дослідженнях спостерігалося навантаження до $2 \mathrm{H}$, що відповідає ходу індентора в динамометрі 0,4 мм. У виробничих умовах такою похибкою можна знехтувати.

Втулка (2), в якій розташовано динамометр та індентор, рухається на пружині (5) та має фіксуючі виступи. Стальний індентор вільно рухається по вертикалі в трубі завдяки змазаним поліетиленовим вставкам (8)

Послідовність дослідження релаксації продуктів наступна: датчик ставиться трубою (3) на продукт i експериментатор натискає на корпус (1) коли зусилля 
перевищує 3Н втулка (2) разом 3 динамометром (4) та індентором (6) вистрелюється завдяки пружині (5). Також в програмі “Лабораторія ITM" запускається процес вимірювання.

Індентор тисне на зразок через поліетиленовий наконечник (7), що не дозволяє прорвати поверхню продукту i забезпечує вимірювання релаксаційного зусилля на межі міцності. Глибина продавлювання індентора в продукт відносно поверхні, на якій стоїть датчик складає 6 мм. Ходом динамометра можна знехтувати. А для зменшення впливу локальних неоднорідностей форми поверхні риби датчик слід встановлювати на рівну поверхню зразка.
В процесі вимірювання спостерігається падіння релаксаційного зусилля (рис. 3). При досягненні падіння релаксаційного зусилля менше, ніж на $0,05 \mathrm{H}$ за кожні 10 c, експериментатор може зупиняти вимірювання та знімати датчик із зразка.

Після проведення дослідження дані експортуються до табличного процесора MS Excel та порівнюються 3 еталонними значеннями релаксації філе риби відповідного виду, розміру та способу зберігання.

Оскільки на структурно-механічні властивості риби впливає багато додаткових факторів, зокрема ступінь вгодованості, вік, спосіб вирощування тощо, то необхідно зробити серію експериментів не менше, ніж 3 трикратним повторюванням.



розробленого датчика: 1 - зона показників динамометра без навантаження, 2 - початкове зусилля, 3 - крива релаксації

Під час експорту даних до табличного процесора слід відкидати області підготовки до експерименту (1), оскільки вони обтяжують і не без того великий числовий масив (5-8 тис. рядків)

Після експорту даних можливий або детальний аналіз кривих через побудову дотичних (Shapoval, 2017), якщо є потреба у кількісній оцінці, або, в більшості випадків, достатньо візуального аналізу і порівняння кривої з еталоном.

Чим швидше відбувається падіння релаксаційного зусилля (крива (3) має менший радіус) тим швидше руйнується структура продукту і тушка риби має меншу пружність, більший термін зберігання. Якщо початкове зусилля (2) суттєво менше ніж в еталонному графіку, за умови порівняння зразків одного віку і терміну зберігання, то 3 високою вірогідністю продукт піддавався заморожуванню.

Результати дослідження релаксаційного зусилля на стиск та на розтяг для тушки білого амуру суттєво відрізняються (рис. 4)

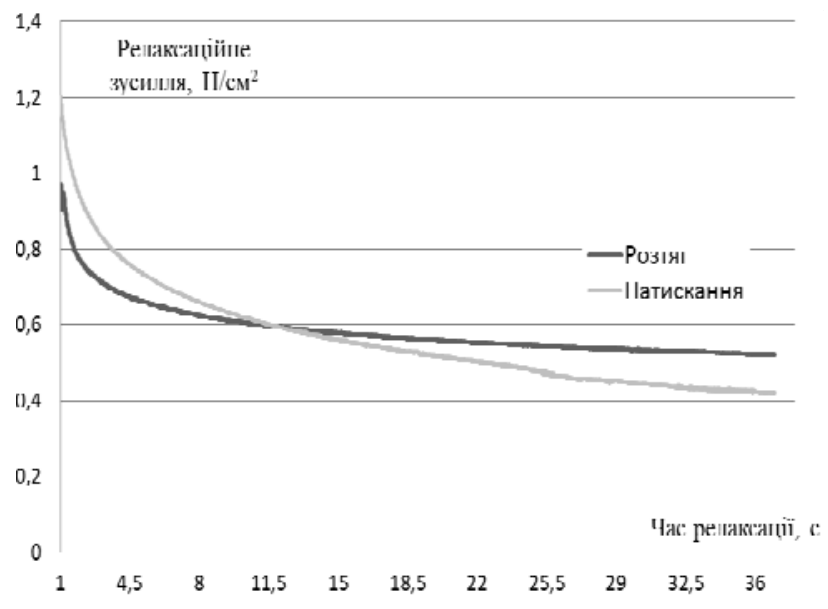

Рис. 4. Динаміка релаксаційного зусилля при стиску та розтягу зразків тушки білого амуру 8 год. зберігання 
На рис. 4 видно, що швидкість релаксації на 1 см² при деформації розтягу на натискання не співпадає. Початкове зусилля при надавлюванні на продукт на 23,5\% більше ніж при розтягуванні зразка аналогічної площі поперечного перерізу.

Згідно опитування експертів-товарознавців КНТЕУ час натискання на поверхню продукту для визначення його пружності складає, в середньому, близько двох секунд.

На наступному етапі було проведено аналіз швидкості релаксації поверхні через порівняння кутів нахилу дотичних до графіків релаксаційного зусилля. Отримано рівняння дотичних на 3 с експерименту (2 с натискання на шкіру тушки):

$$
\begin{aligned}
& F_{\text {rel_r }}=-0.06685 \mathrm{t}+1.039 \\
& F_{\text {rel_ } n}=-0.033 \mathrm{t}+0.815
\end{aligned}
$$

де: $\mathrm{t}$ - час експерименту, c

$\mathrm{F}_{\text {rel_r }}$ - релаксаційне зусилля при деформації розтягу, $\mathrm{H} / \mathrm{cm}^{2}$;

$\mathrm{F}_{\text {rel_n }}$ - релаксаційне зусилля при деформації стиску, $\mathrm{H} / \mathrm{cm}^{2}$

Кут нахилу дотичних до осі (час релаксації) складає $2,82^{\circ}$ для кривої деформації розтягу і $1,89^{\circ}$ для кривої деформації стиску. Отже, структура м'яса білого амура при розтягуванні зразка відновлюється на $33 \%$ швидше, ніж при натисканні на поверхню.

\section{Висновки}

За результатами проведених досліджень встановлено, що релаксаційне зусилля при деформації стиску більш детально описує пружні властивості тушки білого амуру, аніж релаксаційне зусилля деформації розтягу.

Застосування інструментального методики оцінки релаксаційного зусилля деформації стиску для визначення структурно-механічних властивостей риби дозволяє мінімізувати вплив експериментатора на результати під час сенсорної оцінки та отримати кількісні значення швидкості релаксації в будь-який момент часу експерименту.

Розроблена система дозволяє визначити релаксаційне зусилля при здавлюванні зразка риби подібно до того, як це робить товарознавець-експерт та кількісно оцінити його.

Встановлено, що для м'яса білого амура, що зберігалося впродовж 8 год., швидкість релаксації при деформації розтягу на 33\% швидше, ніж при деформації стиску, початкове зусилля при надавлюванні на продукт на 23,5\% більше, ніж при розтягуванні зразка аналогічної площі поперечного перерізу.

Перспективи подальших досліджень. Планується автоматизувати процес натискання індентора на продукт для мінімізації коливань руки експериментатора та тиску корпусу датчика на суміжні області поверхні тушки риби.

\section{References}

Sydorenko, O.V. (2006). Formuvannja asortymentu ta jakosti ryboroslynnyh produktiv: monografija. K.: Kyi'v. nac. torg.-ekon. un-t (in Ukranian).

Sahin, S., \& Servet, G.S. (2006). Rheological properties of foods. Physical properties of foods. Springer, New York. doi: 10.1007/0-387-30808-3 2.

Safronova, T.M. (1998). Spravochnik degustatora rybnoj produkcii. M.: VNIRO (in Russian).

Guc', V.S., Sydorenko, O.V., \& Tymofjejeva, O.V. (2006). Rybni preservy. Nova metodyka vyznachennja konsystencii'. Harchova i pererobna promyslovist', 7, 14-17 (in Ukranian).

Safandowska, M., \& Pietrucha, K. (2013). Effect of fish collagen modification on its thermal and rheological properties. International journal of biological macromolecules, 53, 32-37. doi: 10.1016/j.ijbiomac.2012.10.026.

Guc', V.S., Koval', O.A., Sydorenko, O.V., Tymofjejeva, O.V. (2006). Sposib vyznachennja konsystencii' harchovyh produktiv. Deklaracijnyj patent na korysnu model' №200511305; Zajavl. 29.11.2005; Opubl. 15.05.2006, Bjul. №5 (in Ukranian).

Shapoval, S. (2017). Improved method to determine structural-mechanical properties of turkey meat at axial deformation. Eastern-European Journal of Enterprise Technologies, 1, 10(85), 63-69. doi: 10.15587/1729-4061.2017.93453.

Romanenko, O. (2013). Metod vyznachennia s trukturno-mekhanichnykh vlastyvostei rybnykh preserviv. Tovary i rynky, 2, 58-65. http://nbuv.gov.ua/UJRN/tovary 2013 2 6 (in Ukranian).

Ramírez, J.A., Uresti, R.M., Velazquez, G., \& Vázquez, M. (2011). Food hydrocolloids as additives to improve the mechanical and functional properties of fish products: a review. Food Hydrocolloids, 25(8), 18421852. doi: 10.1016/j.foodhyd.2011.05.009.

Iso, N., Mizuno, H., Saito, T., Wang, Z., \& Narita, M. (1986). The changes in the rheological properties of fish meats during treatment at high temperatures. Nippon suisan gakkaishi, 52(6), 1055-1059, doi: 10.2331/suisan.52.1055.

Shapoval, S.L., Romanenko, R., \& Forostjana, N.P. (2017). Diagnostyka fizychnyh vlastyvostej harchovyh produktiv. Monografija. Kyi'v.: KNTEU (in Ukranian).

Elektronnyj vymirjuval'nyj blok. Prylady. ITM laboratorija. https://www.itm.com.ua/Категорія/prylady. 